\title{
Pre-Service English Language Teachers' Views of the Effective Teacher and Teaching
}

\author{
İngilizce Öğretmeni Adaylarının Etkili \\ Öğretim ve Ö̆̆retmen Üzerine Yaklaşımları
}

\section{Aynur KESEN MUTLU* Yonca ÖZKAN**}

\begin{abstract}
Researchers in the field of foreign language teaching and learning have for a long time conducted studies of learners' perceptions regarding their perspectives, beliefs, thoughts, and values about language learning, the language teacher and language learners. The present study focused on Turkish preservice English language teachers' views regarding the characteristics required for an effective language teacher. The participants in the study were a total of 220 freshman students, aged between 18-20 years old, enrolled in an English teaching program. Data for this study was collected through student paragraphs and interviews and were analyzed by means of thematic analysis. The results suggest that language learners are mostly affected by both cultural and personal factors.
\end{abstract}

Keywords: Foreign Language Learners, Learners’ Perceptions, Culture, Effective Language Teacher

Öz:Yabancı dil eğitim ve öğretimi alanında yapılan basilica çalışmalar öğrencilerin dil öğrenimi hakkındaki inançları, tutumları ve düşüncelerini içermektedir. Bu çalışmanın amacı İngilizceyi yabancı dil olarak öğrenen Türk üniversite öğrencilerinin etkili dil öğretmeninin özellikleri hakkındaki görüşlerini ortaya çıkarmaktır. Çalışmanın verilerini öğrencilerin yazdığı paragraph düzeyindeki metinler ve birebir görüşmeler oluşturmaktadır. Veri analizi tema çözümlemesi tekniğiileyapılımıştır. Bu çalışmanın katılımcıları yaşları 18 ve 20 arasında değişen 220 birinci sınıf İngilizce öğretmenliği lisans öğrencisidir. Bulgular dil öğrencilerinin etkili öğretmen kavramına ait düşüncelerinin kültürel ve kişisel faktörlere dayandığ 1 yönündedir.

Anahtarsözcükler: Yabancı Dil Öğrencileri, Öğrenci Algıları, Kültür, Etkili Dil Öğretmeni

\section{Introduction}

It can be stated that effective teachers contribute to effective learning. For this reason, the question of what makes a teacher effective has long been among the topics of numerous studies in the context of education. In the earliest studies on effective teachers, teacher efficacy was defined as "the extent to which the teacher believes he or she has the capacity to alter student performance" (McLaughlin \& Marsh 1978, 84). Many studies have been conducted to search into the characteristics of effective teachers and it has been concluded that "the general

\footnotetext{
* Assist. Prof. Dr., İstanbul Medipol University, Faculty of Education, English Language Teaching Department, İstanbul. aynur.kesen@gmail.com

** Assoc. Prof. Dr., Çukurova University, Faculty of Education, English Language Teaching Department, Adana. yoncaca@cu.edu.tr
} 
expectations of an effective teacher have not changed significantly over the years but the way they are displayed in the classroom has" (Larsen-Freeman 1986). Hativa, Barak and Simhi assert that "teacher effectiveness is not merely about fitting a particular teacher or conforming to a set of external criteria; rather, it involves understanding what being a good teacher really means and incorporating classroom practices that are appropriate for the wider social context" (2001). Accordingly, Hunt $(2009,1)$ defines teacher effectiveness as "the collection of characteristics, competences, and behaviors of teachers at all educational levels that enable students to reach desired outcomes". Being an important part of education, "foreign language teaching is not an exception for defining effectiveness" (Demiröz \& Yeşilyurt 2015, 862). Çelik, Arıkan, and Caner $(2013,288)$ claim that "in the context of foreign language instruction, classroom instructors are often the only speakers with whom students have the opportunity to interact in the process of developing their language skills; thus, the effectiveness of foreign language teachers is seen (as) especially critical". Since successful foreign language learning could be facilitated by preparing the best learning environment for the learners, searching into the roles and characteristics of an effective language teacher, who is at the very center of the effective learning, becomes crucial.

\section{Purpose of the study}

Exploring the characteristics of a foreign language teacher is crucial as it helps the instructors to improve their teaching and have a clear picture of the learners' perception of an effective teacher. The main purpose of the present study is to search for those qualities that Turkish students enrolled in an English teacher education program at a state university attribute to an effective foreign language teacher. Additionally, the study aims to shed light on the factors that could have an impact on the participants' perception of an "effective foreign language teacher".

\section{The Significance of the study}

Various studies on the attributes of an effective English language teacher have been conducted in numerous contexts including in Turkey (Wong 2000; Borg 2006; Cheung 2006; Malikow 2006; Park \& Lee 2006; Arıkan, Taser \& Saraç-Süzer 2008; Arıkan 2010; Çubukçu 2010; Wichadee 2010; Ghasemi \& Hashemi 2011; Kourieos \& Evripidou 2013; Demiröz \& Yeşilyurt 2015; Baytur \& Razi 2015). The results of these and similar studies have shown that perceptions of effectiveness display both similarities and differences in particular contexts. These studies have also implied that the perceptions of learners of effective language teacher are influenced by personal, cultural, social and economic factors, as well the personal experiences. The results of this study may contribute to the related literature by presenting a list of characteristics that Turkish university students enrolled in an English language education program attach to an effective foreign language teacher. The study may also be useful in practical terms as it helps English language teachers to (1) develop a deeper understanding of the qualities that students associate with an "effective foreign language teacher" and (2) improve their teaching practice accordingly.

\section{Literature review}

\section{Research on effective language teachers}

It is beyond doubt that the teacher, the student and the setting where education takes place are all essential to quality education and language teaching/learning is by no means an exception to these. Research in the field of foreign language teaching/learning has not only contributed to the attempts to make teaching/learning more efficient but also helped teachers and learners to 
become more aware of their traits. The question of what makes a language teacher effective has long been a subject of the utmost importance to many researchers and scholars. Thompson (2008) states that effective teachers do have a combination of strong teaching skills and positive personality traits. Studies in the field of learners' perceptions and beliefs have shown that "learner beliefs vary according to such factors as age, cultural background, learning environment, stage of learning and target language" (Tanaka \& Ellis 2003). In a study by Borg (2006), English language teachers' perceptions of an effective foreign language teacher were investigated. The study revealed that English teachers needed to be up-to -date to cope with the advanced and progressive nature of language teaching. In addition, English language teachers were supposed to have closer, more relaxed and generally more positive relationships with learners in comparison to other teachers. In another study, the desirable characteristics of an effective language teacher were described as having knowledge and command of the target language, being able to organize, explain, and clarify as well as to sustain interest and motivation among students, and being fair to students (Brosh 1996). The finds from a study by Park and Lee (2006) revealed that both for teachers and students English proficiency, pedagogical knowledge and socio-affective skills are essential to the description of an effective language teacher. The characteristics of an effective language teacher were also investigated by Kalebic (2005). The fourteen competences reported in his study were linguistic and communicative competence; communication and presentation skills; ability to motivate learners for learning; ability to choose appropriate teaching strategies; ability to deal with unpredicted situations and to maintain discipline; ability to plan the lesson; ability to organize learning activities; ability of pedagogical action; ability to create friendly atmosphere in the classroom; ability to respond to learner abilities and needs (flexibility); knowledge about teaching strategies; knowledge about the culture and literature in the target language; ability to assess learner language knowledge /competence; and knowledge of methods and theoretical concepts in English language teaching. In line with Kalebic (2005), Thompson (2008) proposed that good language teachers demonstrate patience and respect the learners. He further stated that language teachers are "well prepared, able to select appropriate frameworks for their lessons and able to design interesting tasks". In another study by Wichadee (2010), the characteristics of effective English language teachers perceived by students and teachers were explored. The study revealed that students placed a high level of importance especially on communication and organization skills, while the teachers ranked English proficiency the highest. The study by Barnes and Lock (2013), in which Korean University students' perceptions of effective foreign language teaching were investigated, concluded that language learners place high importance on rapport attributes such as friendliness, care, and patience; and delivery attributes which included the provision of clear explanations, error correction, and a participatory mode of instruction, in addition to impartiality, target language knowledge, and good preparation. In Faranda and Clarke's study (2004), the attributes of the effective language teacher centered around five categories of teacher attributes- rapport, delivery, fairness, knowledge and credibility, and organization. The study by Sakurai (2012) with 492 language course students from five different Arab countries revealed that the participants placed a higher value on the language teachers' knowledge and experience, practical teaching, support for students' learning, and the attempt to create a friendly atmosphere. In another study by Wichadee and Orawiwatnakul (2012), the effective language teachers' skills included organization and communication skills and socio-affective skills. The study by Shishavan (2009) investigated the characteristics of an effective English language teacher as perceived by Iranian teachers and learners of English. It was concluded in the study that teachers' personality and the way he behaves toward his students were among the most important characteristics 
listed by the participants. Kourieos and Evripidou's study (2013) with Cypriot students showed the effective language teacher is the one who takes into consideration his/her students' individual differences, language anxiety, abilities and interests and designs the learning environments accordingly.

\section{Studies on learners' perceptions of effective language teacher in the Turkish context}

Many researchers have also investigated language learners' perceptions of the qualities attributed to the effective teacher in the Turkish context, where the present study was conducted. In a study by Arikan, Taser, and Süzer (2008), Turkish EFL students' conceptualization of an effective English language teacher was studied. The results of the study indicated that an effective teacher is a friendly, young, enthusiastic, and humorous person whose gender is not important. In another study by Telli, den Brok and Çakıroğlu (2008), the greatest importance among the attributes of an effective language teacher was given to the positive teacher-student interaction by the participants of the study. Koç’s study (2012) concluded that Turkish language learners wanted their teachers to avoid discrimination and to be patient. The participants also stated that they wanted their teachers to keep order in the classroom, increase their motivation, pay attention to their needs and build good relationship between them. In another study conducted in the Turkish context, Çubukçu (2010) found that the most important quality that the language teachers should have was caring about the students and their learning. In addition, characteristics such as increasing the students' motivation and interest were also listed as important attributes by the participants. The study by Çelik, Arıkan, and Caner (2013) with 998 Turkish undergraduates concluded that being fair and just, showing enthusiasm, friendliness, being loving, creativity, being experienced, and being humorous were reported as the qualities of an effective language teacher. Demiröz and Yeşilyurt (2015) in their study of prospective English language teachers revealed that an effective language teacher should teach communicatively and indirectly correct students' mistakes.

\section{Culture and learner beliefs}

Although defined in various forms, culture is most commonly used to refer to the set of shared customs, beliefs, or values that distinguish one community from the others. That is, culture implies a group of people "who have similarities in their way of thinking" (Majid 2008, 127). As in determining the way a group, society, or community think, culture influences the learners' view of learning and their teachers. Research in the field of learning has also focused on how culture influences learning (Bauer 2000; Merriam \& Mazanah 2000; Kim \& Bonk 2002). Chin, Chang, and Bauer (2000) studied the influence of learners' cultural background on their perceptions of learning. They concluded that Anglo-Saxon students were more confident with web-based learning as compared to the Asian students. In another study by Kim and Bonk (2002), cross cultural differences in collaborative on-line learning among Finnish, American and Korean learners was researched. The study yielded differences in learning, motivation and approach. As for the differences between the Western and Eastern educational context, the studies focused on how the values of a specific culture affect learners in regard to such issues as learning styles, learner perceptions, learner beliefs, and teacher roles. The table below presents the differences between the West and East with a focus on the learner. 
Table 1. The Differences between the West and East with a Focus on the Learner

\begin{tabular}{|c|c|}
\hline East & West \\
\hline $\begin{array}{l}\text { - Collective and interdependent behavior } \\
\text { - Being in harmony with nature, relationships and } \\
\text { cooperation } \\
\text { - Knowledge: from teachers and books } \\
\text { - Group support, social and moral learning } \\
\text { - Learning through practice and memorization } \\
\text { towards mastery: preparation, repetition, } \\
\text { confidence building } \\
\text { - Hierarchical relations: agreement, harmony, face, } \\
\text { respect } \\
\text { - Teacher as model, expert, authority, parent, friend, } \\
\text { teacher-centered }\end{array}$ & $\begin{array}{l}\text { - Self-reliance, personal achievement and } \\
\text { autonomy } \\
\text { - Competition, control and production } \\
\text { - Skills: in communicating and learning } \\
\text { - Personal needs, attention, unique things } \\
\text { - Learning through interaction and } \\
\text { construction: experience, activities, tasks, } \\
\text { initial creativity } \\
\text { - Horizontal relations: discussions, argument, } \\
\text { informality } \\
\text { - Teacher as organizer, mentor, guide, helper, } \\
\text { learner-centered }\end{array}$ \\
\hline
\end{tabular}

As seen in Table 1, there are some differences between east and west cultures in regard to the role of a learner, learning process and the role of a teacher. While learners in eastern cultures prefer learning through practice and memorization towards mastery, learners in the western cultures depend heavily on learning through interaction and construction. Another difference reveals itself in learners' relations with teachers. In eastern cultures, hierarchical relations (agreement, harmony, face and respect) seem to be of great importance; however, in the western cultures more emphasis seems to be put on horizontal relations (discussions, argument, informality). Learners in both cultures also differ in the way they perceive the concept of a teacher. The teacher in the eastern cultures is expected to be a model, expert, authority, parent, and friend; in contrast, learners in the western cultures expect the teacher to be an organizer, mentor, guide, and helper. Such differences may also have an impact on the way learners in different cultures perceive "teacher effectiveness".

\section{Method}

In this study, qualitative research design was adopted in order to gain deeper knowledge and a clearer perception of the participants. As the participants' own reflections, experiences and views were chosen as a guiding force for this study, it was thought that qualitative data collection and analysis methods would embrace the research content much more effectively. The study is a descriptive case study which describes Turkish pre-service English language teachers' views regarding the characteristics of an effective language teacher.

\section{Participants}

The participants consisted of 220 students of the English Language Teaching Department of Cukurova University in Adana, Turkey. The students in this study were all first year university students in the academic year 2015-2016. All the participants were Turkish and they were all aged between 18-20. The mean age was 19.5 among the participants. 166 (75\%) of the participants were female and 54 (25\%) were male.

\section{Instrumentation}

The data in this study were gathered by paragraph writing about the effective language teacher and semi-structured face-to-face interviews. Of the 220 students 198 of the participants wrote a paragraph on the targeted topic and interviews were conducted with $10 \%$ of the participants (n.20). Each of the participants was interviewed in a semi-structured format. Interviews are very 
well known communication methods and this fact allows them to be used effectively and conveniently as a research instrument in qualitative studies. Among interview types, semistructured interviews are largely employed as they encourage an opportunity to speak freely on a targeted topic or issue and to make additional comments and interpretations (Dörnyei 2007).

Paragraph writing was chosen as another tool for collecting a comprehensive and authentic set of data on the targeted issue in the current study.

\section{Procedures for data collection}

During the data collection process, some main ethical issues were considered: a) voluntary participation, b) informing the participants about the research content, c) receiving the participants' consent before starting the research, and d) making sure that the rights and interests of the participants' were protected (Creswell 2013). In the analysis of papers and interviews, the names of the participants were all covered and only codes were used in order to protect their privacy. For confidentiality, the data were not shared with anyone apart from the researchers of the current study. The following steps were followed during students' paragraph writing process:

- The students were asked to write one paragraph describing an effective language teacher.

- The students wrote their paragraph in their regular class hour specifically in their writing course.

- In analyzing the papers to list the characteristics of an effective language teacher, the researchers both read each student's paper and came up with the themes for providing inter- rater reliability of the analysis.

- The researchers compared and contrasted their list to negotiate on the common themes and labeled them.

In the interview session, the participants were asked to elaborate on the characteristics of an effective language teacher. The interviews were conducted to validate the data gathered from the essays. The duration of each interview varied from eight to ten minutes. The interviews were transcribed and coded using Seventh String Software version 7.50.0 for Mac. During the interviews, unstructured follow-up questions were used to elicit more information on the topic and to clarify the unclear points made by the interviewees. These questions included: Could you explain what you want to say?, What do you mean by ..?. Could you give me an example? The interviewers were careful not to give their ideas on the topic and not to ask private questions. The participants were assured of the confidentiality of their responses. This made them certain that their responses would not be revealed under any circumstances. In addition, member checking was conducted with the participants to help ensure authenticity, validate the findings and interpretations (Miles \& Huberman 1994) and 17 of the participants confirmed the accuracy of the transcribed interview data.

\section{Procedures for data analysis}

The analysis of the interviews and student papers was composed of recurring themes which is a widely used method in all kinds of qualitative studies (Glaser \& Strauss 1967). Thematic analysis was conducted based on Creswell's (2013) steps: a) preparing and organizing data, b) reducing the data into themes via a process of coding and condensing the codes, and c) presenting the data in verbal form as well as with figures and tables (p.180). This strategy starts with a single incident from the interview data and then continues with comparing that incident with others within the data. This includes reading the transcripts several times comparing and contrasting them with similarities and differences till the incidents are aggregated into themes. While listing 
the themes, the researchers moved backwards and forwards between transcripts, and the research literature. The researchers systematically worked through each transcript assigning codes, which were the specific characteristics regarding teacher roles.

The data gathered through student essays and interviews were coded and categorized under the following four aspects: pedagogical knowledge, subject-matter knowledge, socio-affective skills, and personality characteristics. The aspects used in the current study were based upon previous studies and categories of the effective language teacher (Arikan et al. 2008; Barnes \& Lock 2013; Dinçer et al. 2013; Erbay et al. 2014). The results were analyzed both quantitatively and qualitatively.

\section{Results}

This study aimed to research Turkish pre-service English language teachers' views regarding the characteristics of an effective language teacher. Data obtained through paragraph writing about the effective language teacher and semi-structured face-to-face interviews were analyzed through thematic analysis. Qualitative data analysis results were presented with regard to the categories defined by the participants. The following section presents a detailed account of each category.

\section{Teacher's help}

The analysis shows that the aspect with the second highest frequency (f: 85 ) is the pedagogical knowledge skills of the teachers (teacher's help and teacher as the authority) from the perspective of the participantsof the current study (Table 2). That is, the teacher/s being scaffolder or support has the most outstanding value (25.5\%) in the participants' lives. This result may be attributed to the students' need to feel secure and not to take risks in the language learning process. This may even be related to the fact that they may not be aware of their learning strategies so that they tend to get help from their teachers. Another reason why students want to get support from the language teacher might be attributed to the cultural values of the students.

\section{Pedagogical knowledge}

Table 2. Characteristics of the Effective Language Teacher from the Perspectives of Preservice English Language Teachers

\begin{tabular}{|l|c|c|}
\hline Category & f & $\%$ \\
\hline Pedagogical knowledge & & \\
\hline Teacher's help & 53 & 21.4 \\
\hline Teacher as the authority & 32 & 13.0 \\
\hline Subject-matter knowledge & & \\
\hline Knows about the target culture & 27 & 10.9 \\
\hline Personality characteristics & & \\
\hline Tolerance & 30 & 12.1 \\
\hline Teacher as a humanist & 19 & 7.7 \\
\hline Friendliness & 18 & 7.2 \\
\hline Intelligence & 16 & 6.4 \\
\hline Fairness & 11 & 4.4 \\
\hline Enthusiasm & 10 & 4.0 \\
\hline Sense of humor & 10 & 4,0 \\
\hline Forgiveness & 10 & 4.0 \\
\hline Open-mindedness & 6 & 2.4 \\
\hline Creativity & 5 & 2.0 \\
\hline
\end{tabular}

That is, since the participants are all from Turkey in which eastern cultural values are dominant such as the tendency to receive knowledge from two sources: either from the teacher or the book, the participants prefer the help of the teacher instead of being responsible for their own learning(Fry 1990; Thomas 1991; Hofstede 1991; Merriam \& Muhamad 2000; Wong 2000). Chuah (2009) claims that "compared to Western students, East- Asian students are more dependent on their lecturers. Their dependence on their parents when at home immediately transfers to their lecturers when away from home." This specific characteristic (teacher's support) is highlighted in the following verbatim:

\section{S1. I cannot concentrate on my studies without professional help.}


S2. Since I make many mistakes I prefer my teacher' help.

S3. To me, an effective teacher helps his students to overcome the difficulties of learning English.

\section{Teacher as the authority}

Another skill that the participants believe that an effective language teacher should have is "having the authority". We see in Table 2 that participants do want to see the teacher as authority (13\%) in the language class. The verbatim below focuses on the authority theme:

\section{S1. A good teacher should control the class and have good management} skills.

S2. To me, an effective teacher is the one who has the power in class.

S3. The students should know the rules of the class. They should know when to speak and when to keep silent. The rules should be set by the teacher.

The findings of the current study in respect to teacher's authority are in line with the studies conducted both in Turkey and abroad (Kourieos \& Evripidou 2013; Erbay et al. 2014). However, the high frequency of "teacher's authority" in the present study contradicts the lower frequency of "teacher's authority" in the study by Arikan et al. (2008) which was also conducted in the Turkish educational context. The reason why such a contradiction occurs may result from the level of the students and individual differences of the participants in these studies.

The studies investigating the effects of culture on the language learners' perceptions indicate that teachers are regarded as the authority or controller in eastern cultures as opposed to western cultures where teachers are seen as mentor or guide (Fry 1990; Thomas 1991; Hofstede 1991; Merriam \& Muhamad 2000; Wong 2000). In some cultures, learner autonomy is not valued highly, the students may become confused by, and even resist, exhortations to greater selfdirectedness in learning. More to the point, once we admit that learning/acquisition of skill in practice does involve transmission of knowledge; we must also admit dependence upon the intellectual authority of those persons responsible for transferring that knowledge as an inevitable aspect of education. Yet dependence too is a situational attribute, one that is "momentary, situationally specific and therefore changeable" (Pratt 1988, 170). The reason why "teacher's having authority in the classroom" was highly emphasized in the current study may stem from "the culture in that in collectivist and high-context cultures such as Turkey, teachers have an unshakable authority in the classroom and respecting a teacher is in direct proportion to authority" (Erbay et al. 2014). In the study by Erişti (2012), the focus on discipline was attributed to the education system of Turkey.

\section{Subject-matter knowledge}

\section{Knows about the target culture}

As can be seen in Table 2, the participants believe that an effective language teacher should know about the target culture (10.9). Knowledge of the target culture is the only item that fits into the category of Subject-matter knowledge of an effective teacher. The results of the items pertaining to the important qualities an effective teacher should possess indicate that among the characteristics shown in Table 2, the teacher's knowledge about the culture of the language s/he teaches is the fifth most frequently mentioned characteristic by the participants. The reason why a language teacher should teach about the target culture might stem from the learners need to 
communicate better in the target language. That is, as Çakır (in Aydemir \& Mede 2014) implies "knowing and understanding a language does not only mean to acquire the knowledge of grammar and lexis, but also the features and characteristics of the culture on some level". The verbatim below clarifies why in the eyes of Turkish ELT students it is important for the language teacher to know and teach about the target culture.

S1. The teacher should teach us how people communicate abroad. If I learn about the target culture, I can communicate better.

S2. If I know how people dress, eat or talk in England or America, I can perform better when I speak in English.

S3. To me, an effective teacher should certainly teach cultural issues in the language classroom. Learning about a new culture is important and necessary for becoming a better speaker.

The findings of the present study pertaining to being knowledgeable about the target culture as one of the important qualities of an effective language teacher are in line with the studies by Borg (2006), Arikan et al. (2008), Kourieos \& Evripidou (2013), and Erbayet al. (2014) which concluded that the teacher's knowledge of the target culture was one of the important attributes of an effective language teacher. However, it might be noteworthy to mention that the present study differs from the related studies in that the item "being knowledgeable on target culture" had a higher frequency, as compared to the frequencies for the same item in the other studies by Arıkan et al. (2008), Kourieos \& Evripidou (2013), and Erbay et al. (2014).

\section{Personal characteristics}

\section{Tolerance}

Results concerning the personal qualities of an effective language teacher showthat for the participants of the current study, tolerance is among the set of qualities that an effective teacher should possess. It is seen in Table 2 that the most frequently mentioned item in the category of personal characteristics is "tolerance" (12.1\%). Among all the attributes mentioned by the participants, the teacher being tolerant is the third most frequently attribute preceded by the items "teacher's help" and "teacher's authority". That is, for 30 of the participants, an effective language teacher should be tolerant, in addition to being helpful and having authority in the language classroom. The participants in this study believe that lessons will be more enjoyable and they could learn more easily when their teachers appear tolerant. The verbatim below sheds light on why learners regard "tolerance" as a desirable characteristic of an effective teacher.

S1. A good teacher should be tolerant of us and our behavior in class.

S2. I want to have class with a tolerant teacher because I want a relaxed atmosphere.

S3. To me, an effective teacher tolerates our mistakes in class.

The results of this study are consistent with the related research literature in that Cheung (2006), Shishavan (2009), and Lupascu, Panisoara \& Panisoara (2014) all indicate the importance of teacher being tolerant as an essential attribute of an effective language teacher.

\section{Teacher as a humanist}

With this theme, the participants of the study believed that the language teacher should possess a humanitarian (7.7\%) style in class, especially in three domains: understanding the students' needs, assigning tasks or projects and handling discipline in class. 
S1. We need rewards not punishment. We want to see teachers with smiling face.

S2. When the teacher makes me believe that I am important, I feel happy.

S3. The teacher should pay attention to how we feel in addition to how well we do in the classroom.

It is seen in Table 2 the teacher adopting a humanitarian approach in class is the second most frequently mentioned item by participating students $(7.7 \%)$ in the category of personal characteristics. That is, for 19 of the participants, being a humanist is essential for a language teacher. The reason why "the teacher as a humanist" received quite a high frequency as can be seen in Table 2 might stem from "the implications of humanistic philosophy which is based on the idea that close personal relationships give meaning to the whole process of teaching and learning and humanistic teachers are usually aware of the importance of personal freedom, choice and self-determination" (Al-Khalidi 2015). The results of the current study pertaining to the teacher being humanist are in line with other studies. That is, the importance of the teacher adopting the basic principles of humanistic education also appears in studies by Açıkgöz, 2005; Arıkan et al. 2008; Baytur \& Razı 2015; Dinçer et al. 2013; Erbay et al. 2014; Shahmohammadi 2015. The results of these studies also imply that an effective teacher should consider the students' feelings as well as their knowledge in the process of learning and create a non-threatening environment in which students learn better.

\section{Friendliness}

The quantitative results displayed in Table 2 show that an effective teacher is a friendly person. That is, for $7.2 \%$ of the participants, a friendly teacher is regarded as more effective in teaching. Among the qualities displayed under the category "personal qualities" friendliness is the third most frequently mentioned attribute by the participants. The verbatim below clarifies why friendliness is an essential trait for a language teacher.

S1. When the teacher is angry, I get demotivated but a friendly teacher makes learning an enjoyable activity.

S2. The teacher should be friendly because learning English is difficult and if the teacher is friendly I can easily talk to him and feel much better.

S3. An effective language teacher is the one who forms a positive relationship with the students.

The results of this study are consistent with the studies conducted by Clark and Walsh (2002), Cheung (2006), Arıkan et al. (2008), Shishavan (2009), Wichadee and Orawiwatnakul (2012), and Erbay et al. that concluded that friendliness is one of the most important attributes of a language teacher. However, it might be worthwhile to mention that while friendliness was found to be the most desirable quality of an effective language teacher in respect to personal traits in the studies by Saraç-Süzer (2007), Telli et al. (2008), and Çelik et al. (2013), in the current study being friendly was the third most frequently stated item and it was preceded by the teacher being humanist and having tolerance. The reason why friendliness is perceived as an important quality of a language teacher may be attributed to culture. It is claimed that the learners in the East perceive the teacher as a model, expert, authority, parent, and friend, as distinct from learners in the West who perceive the teacher as an organizer, mentor, guide, and helper (Fry 1990; Thomas 1991; Hofstede 1991; Merriam \& Muhamad 2000; Wong 2000). 


\section{Intelligence}

As can be seen in Table 2, 6.4\% of the participating Turkish pre-service English language teachers believe that an effective language teacher should be intelligent. It seems worthwhile to mention that intelligence was the fourth most frequently mentioned item by the participants. The reason why the participants appreciate the teacher's intelligence may be linked to another finding in the present study: the teacher as the authority. We may infer that the participants who believe that the teacher should have control and thus be superior to the students should also be intelligent which will lead to a more fruitful lesson. The following verbatim clarifies the students' views

S1. If the teacher is intelligent, she can teach us better.

S2. An effective language teacher should be intelligent because teaching a foreign language is difficult.

S3. The teacher should be intelligent enough to deal with the problems in the classroom. She is the one who knows the best in the classroom. Students trust the teacher because she knows more than the students.

It is interesting that the participants seem to consider academic intelligence, not emotional or social intelligence, as an essential quality of an effective language teacher. The reason why the participants value the academic intelligence of the teacher may stem from cultural and personal differences. Since the teacher is believed to be the source of knowledge in Eastern cultures including Turkey, the academic aspect of intelligence may have received priority over social or emotional intelligence.

\section{Fairness}

In the categories of teacher attributes provided by Faranda \& Clarke (2004), fairness includes grading, impartiality, examination relevance, transparency, and workload. It is seen in Table 2 that $4.4 \%$ of the participants perceive fairness as an essential quality of an effective teacher. Since language learning is a demanding process for foreign language learners, even a little unfair treatment by the teacher can cause dislike of learning on the part of the student. The representative quotations from the interview of the participants regarding fairness clarify how fairness is viewed in the present study.

S1. I like to be treated fairly in class. I can only trust my teacher if she is objective among my classmates.

S2. We are all in the same class at the same age and at the same level so our teacher should treat us as equal.

S3. The teacher should give the same homework to all of us.

It is clearly understood from the quotations that for the participants of this study, an effective teacher should be fair and s/he can achieve this by being objective in treating students and assigning the same homework to every student in the classroom.

Fairness was also found to be an important attribute of an effective teacher in the studies conducted both in Turkey and abroad (Brosh 1996; Simpson \& Mengi 2011; Çelik, Arıkan \& Caner 2013; Barnes \& Lock 2013; Gao \& Liu 2013).

\section{Enthusiasm}

The results in Table 2 provide evidence that enthusiasm is another essential characteristic for the participating Turkish pre-service English language teachers. For 10 of the participants, it is necessary for a language teacher to be enthusiastic to be effective. The findings of the current 
study are in line with the studies by Baytur \& Razı (2015), Gao \& Liu (2013), Çelik, Arıkan, and Caner (2013), Arıkan et al. (2008) and Malikow (2006) that concluded that enthusiasm is an important attribute of an effective language teacher. However, it might be worthwhile to mention that while enthusiasm received one of the highest scores in the personal qualities category in the study by Çelik, Arıkan, and Caner (2013), being enthusiastic was preceded by such personal qualities as tolerance, friendliness, intelligence and fairness in this study. During the interviews when the participants were asked to elaborate on the reasons why enthusiasm is important in teaching, they mostly mentioned the teacher's (1) passion for teaching, (2) being active all the time, and (3) engaging the students. The following excerpts clarify the students' perceptions of an enthusiastic teacher.

S1. The teacher should have passion for teaching. She should love teaching and this will help students to love learning and being in the classroom. If the teacher enjoys teaching, the students will certainly love learning. This is important especially when the students are learning English because learning English is difficult.

S2. To me, an effective teacher is an energetic teacher. Students can lose their motivation easily. Energetic teachers always motivate students.

S3. An effective teacher should be enthusiastic. Students can sometimes get bored and lose concentration on the subject. Although it may be difficult for the teacher, she should find a way to make the students participate in the lesson and she can do this if she loves and enjoys teaching.

From the cultural perspective, it might be concluded that for Turkish students, enthusiasm is one of the important attributes of an effective teacher. As it is known, in eastern cultures including Turkey, confidence building, social learning, and knowledge from teachers are all essential in the learning process (Fry 1990; Thomas 1991; Hofstede 1991; Merriam \& Muhamad 2000; Wong 2000). For this very specific reason, Turkish students might expect the teacher to be enthusiastic who would "establish a positive learning environment by showing their passion for the subject matter, using student names, reinforcing student participation during class, being active in moving among the students, establishing a classroom environment that allows for a high degree of student achievement" (Bulger et al. 2002).

\section{Sense of humor}

It is seen in Table 2 that the teacher having a sense of humor is one of the attributes that participants associate with effective teaching. 10 of the participants in the present study perceive the teacher being humorous as an essential attribute that an effective teacher should possess. It is also seen in Table 2 that the teacher having a sense of humor, being loving and enthusiastic all received the same frequency. In other words, for the participants in this study being humorous, enthusiastic and loving are equally important for being an effective language teacher. The verbatim below clarifies why a sense of humor is essential for effective teaching.

S1. An effective teacher should have a sense of humor. Teacher's sense of humor reduces students' stress in the classroom.

S2. Humorous teachers can easily increase students' motivation; as a result, students learn better in a more relaxing atmosphere.

S3. Teacher-student relationship is very important in the classroom. The students should feel relaxed. If the teacher has a sense of humor, the 
students will have a positive relationship with the teacher and this will help them learn better.

The findings of the present study in respect to having a sense of humor are in line with the studies conducted both in Turkey and abroad (Açıkgöz 2005; Walker 2008; Çelik, Arıkan \& Caner 2013; Gao \& Liu 2013; Baytur \& Raz1 2015) which concluded that having a sense of humor is one of the essential qualities of an effective language teacher.

As can be understood from Table 2, the teacher having a sense of humor received a lower frequency as compared to the frequencies for "tolerance" "intelligence" and "friendliness". The reason why "sense of humor" was not perceived as being as important as the "friendliness" or the "intelligence" of the teacher could be attributed to culture. It is known that "in collectivist and hierarchical cultures (including Turkey where the current study was conducted), jokes tend to be contextual and therefore hard to isolate from the conversation in which they occurred" (Hofstede et al. 2005). That is, the teacher's sense of humor might cause offense on the part of some students or some students may have some strict perceptions regarding the use of humor in the classroom. For all the reasons stated above, the participants of this research may have considered the quality "sense of humor" as a less important attribute of an effective teacher.

\section{Forgiveness}

As indicated in Table 2, forgiveness was also perceived as an essential quality of an effective teacher by the participants in the present study. We see in Table 2 that for 10 of the participating Turkish pre-service English language teachers, an effective language teacher should be forgiving. The following excerpts obtained during the interviews clarify the participants' views on the importance of forgiveness as an essential quality of an effective teacher.

\section{S1. The teacher should forgive students if they display inappropriate behavior in the classroom. \\ S2. An effective teacher should be forgiving because when the students know that even if they do something wrong the teacher will always be understanding and forgiving, this will make them feel relaxed. \\ S3. The teacher should be forgiving because this will create a more positive learning environment.}

The findings of the present study are in line with Walker's study (2008) in which it was concluded that the teacher being forgiving is one of the essential qualities of an effective teacher.

It might be worthwhile to mention that "forgiveness, which may be a means to maintain harmony and should be granted, may be perceived to be an obligation in Eastern (collectivist) cultures" (Terzino 2007). The reason why participants in the current study perceive the teacher's forgiveness as an important characteristic of an effective teacher might be attributed to their being part of a collectivist culture in which the teacher, like other individuals in the society, is expected to be forgiving.

\section{Open-mindedness}

Results concerning teacher's being open-minded show that as compared to the items "tolerance" and "friendliness", the teacher being "open-minded" had a much lower frequency (Table 2). That is, only 2,0 \% of the participants of the present study regard open-mindedness as an essential attribute of an effective teacher. When asked to elaborate on why open-mindedness is an important quality of an effective teacher and the participants gave the following responses 
S1. The teacher should be open-minded. She should be open to different suggestions and activities in the classroom.

S2. The teacher should accept different views in the classroom. Sometimes, I think of an alternative way of doing the activity and I want to share this with my teacher.

S3. We should be able to tell the teacher if we do not like some activities.

The results of the current research are in line with the studies by Cheung (2006) and Kourieos and Evripidou (2013) which also concluded that from the perspectives of the learners, an effective teacher should be open-minded.

\section{Creativity}

As can be seen in Table 2, only a small number of participants (2.0\%) associate the teacher being creative with effective teaching. It is interesting that "creativity" received the lowest frequency among all the other attributes in the same category. To elaborate on the reasons why creativity is essential, the participants stated the following during the interviews:

S1. Creative teachers always find different ways of teaching. They find interesting activities, they use technology and thus they can motivate the students in the classroom.

S2. An effective language teacher should be creative because in learning English the students need interesting and enjoyable techniques.

S3. We need creative teachers who can find a way to motivate us. Creative teachers are also open to new ideas in the classroom, which makes learning fun.

The findings pertaining to creativity are consistent with the related research literature in that Baytur \& Razı (2015), Çelik, Arıkan \& Caner (2013), Malikow (2006), and Walker (2008) all point to the importance of the teacher being creative as an essential attribute of an effective teacher. However, the present study differs from the studies in the related literature in that the attribute "creativity" received the lowest frequency among the personal characteristics, while the teacher being creative was found to be one of the most frequently mentioned qualities in the studies by Baytur \& Razı (2015), Çelik, Arıkan \& Caner (2013), and Walker (2008).

\section{Discussion and Conclusion}

This study shows that effective language teachers have or demonstrate pedagogical and subjectmatter knowledge and some particular personality traits. It also indicates that cultural and individual differences account for the learners' perceptions of effectiveness in teaching. The analysis of the learners' essays and semi-structured interviews provide a detailed description of how Turkish pre-service English language teachers perceive an effective English language teacher. The results of the present study support the findings of previous research which indicate that effectiveness in teaching is closely related to pedagogical knowledge including the teacher's help and authority (Arikan et al. 2008; Erbay et al. 2014; Kourieos \& Evripidou 2013). Findings of the current study which indicate that an effective language teacher knows about the target culture as a part of subject-matter knowledge are also in line with the studies by Arikan et al. (2008), Borg (2006), Erbay et al. (2014), Kourieos \& Evripidou (2013) and which support the view that effective language teachers have knowledge of the target culture. Similarly, the view that important characteristics of an effective foreign language teacher include friendliness, humanism, tolerance, fairness, open-mindedness, intelligence, enthusiasm, creativity, sense of 
humor and forgiveness is supported by the studies in the related literature (Brosh 1996; Clark \& Walsh 2002; Açıkgöz 2005; Cheung 2006; Arıkan et al. 2008; Walker 2008; Shishavan 2009; Simpson \& Mengi 2011; Wichadee \& Orawiwatnakul 2012; Salahshour \& Hajizadeh 2013; Barnes \& Loc 2013; Gao \& Liu 2013; Çelik, Arıkan \& Caner 2013; Dinçer et al. 2013; Erbay et al. 2014; Lupascu, Panisoara \& Panisoara 2014; Baytur \& Raz1 2015; Shahmohammadi 2015).

The findings of this study and previous studies suggest that pedagogical knowledge, subjectmatter knowledge and personality traits account for effectiveness in language teaching. However, the present study differs from the other studies conducted with the same participant profile, in that Turkish participants in this study place greater importance upon the teacher's personal attributes as compared to pedagogical knowledge and subject-matter knowledge that an effective teacher should have. The current study also indicates that teacher's help, authority and tolerance are the three most important attributes that an effective teacher should possess. In a more specific frame, for Turkish pre-service English language teachers, the profile of an effective language teacher can be described as the one who;

- helps learners

- has authority in the classroom

- knows about the target culture

- is friendly

- is humanist
- is tolerant

- is fair

- is open-minded

- is intelligent

- is enthusiastic
- is creative

- has sense of humor

- is forgiving

The cultural influences observed in this specific study reflect the Eastern cultural values such as the teacher as the authority, teachers' help, teacher as a humanist, friendliness, forgiveness, the teacher's sense of humor, and the teacher's enthusiasm.

\section{Suggestions for further research}

It might be worthwhile to indicate that this study is limited to learners' essays and semi-structured interviews. Therefore, more in-depth qualitative studies might contribute to investigating the qualities that learners perceive as important in being an effective language teacher. As can be expected, all the qualities that the participants stated in this study imply subjectivity in the way learners' perceive an effective language teacher. Since the learners' constructs regarding effectiveness display differences, both in content and nature, it might also be illuminating to investigate how the constructs that learners have are structured and how these constructs change over time. Further research which includes the perceptions of learners studying at different levels might contribute to a greater understanding of effectiveness in language teaching. It might also be helpful to search into the learners' language proficiency, academic qualifications, and what these qualities mean to learners as these variables might illuminate the learners' perceptions of an effective foreign language teacher.

\section{Implications}

It is believed that teacher effectiveness is vital for students' success and it is important to investigate how the characteristics of a teacher influence the students' achievements, as well as the environment in which learning and teaching occur. This study, as well as the studies reported in the related literature indicate that from the perspective of the students, the attributes that an effective language teacher should possess changes depending upon the learners' personality, gender and age, culture, educational background and other variables. For this reason, teachers continually try to "change their teaching styles to fit their learners' needs and expectations" (Çelik, Arıkan \& Caner 2013). It should be within the responsibilities of teachers to investigate 
the perceptions of learners and their own perceptions pertaining to their effectiveness in teaching as well as becoming aware of how these qualities defined by learners shape the learning and teaching context. And the quote from William Arthur Wardbelow best exemplifies the potential influence of any effective teacher on a learner.

"The mediocre teacher tells. The good teacher explains. The superior teacher demonstrates. The great teacher inspires”. William Arthur Ward

\section{Acknowledgements}

We would like to express our sincere appreciation to all the students who so graciously agreed to participate in our study.

\section{Ethics statement:}

The study was undertaken in line with the Çukurova University ethics procedures and guidelines as stated in the Official Paper dated on 16.06.2013 and numbered 28679.

\section{Conflicts of interest statement:}

The authors have no involvement whatsoever in any organization with any financial/non-financial interest in the subject discussed in this work. 


\section{REFERENCES}

Açıkgöz F. (2005). "A Study on Teacher Characteristics and Their Effects on Students' Attitudes”. The Reading Matrix 5/2 (2005) 103-115.

Al-Khalidi N. M. S. (2015). The Relationship Between Humanistic Teachers' Characteristics Practices and Students' Learning. Global Science Research Journals 3/2 (2015) 170-174.

Arıkan A. (2010). "Effective English Language Teacher from the Perspectives of Prospective and In-Service Teachers in Turkey”. Electronic Journal of Social Sciences 9/31 (2010) 209-223.

Arıkan A., Taşer D. \& Saraç-Süzer H. S. (2008). "The Effective English Language Teacher from the Perspectives of Turkish Preparatory School Students”. Education and Science 33/150 (2008) 42-51.

Aydemir E. \& Mede E. (2014). Integrating Target Culture in EFL Classrooms. Turkish Online Journal of Qualitative Inquiry 5/1 (2014) 13-38.

Barnes B. D. \& Lock G. (2013). "Student Perceptions of Effective Foreign Language Teachers: A Quantitative Investigation from a Korean University”. Australian Journal of Teacher Education 38/2 (2013) 18-36.

Bauer J. (2000). "Multiculturalism, Cultural Community: Is It About Culture or Ethnicity? The Canadian approach”. Cultural Policy 7/1 (2000)77-95.

Baytur B. \& Razi S. (2015). “The Characteristics of Effective EFL Teachers from the Perspective of Turkish EFL learners”. International Journal of Human Behavioral Science 1/2 (2015) 1-9.

Borg S. (2006). "The Distinctive Characteristics of Foreign Language Teachers". Language Teaching Research 10 (2006) 3-31.

Brosh H. (1996). "Perceived Characteristics of the Effective Language Teacher”. Foreign Language Annals 29/2 (1996) 125-136.

Bulger S., Mohr D. J. \& Walls R. T. (2002). "Stack the Deck in Favor of Your Students by Using the Four Aces of Effective Teaching”. The Journal of Effective Teaching 5/2 (2002).

Çelik S., Arıkan A. \& Caner M. (2013). "In the Eyes of Turkish EFL Learners: What Means an Effective Language Teacher?”. Porta Linguarum 20 (2013) 287-297.

Cheung H. Y. (2006). “The Measurement of Teacher Efficacy: Hong Kong Primary In-Service Teachers”. Journal of Education for Teaching 32/4 (2006) 435-451.

Chin K. L., Chang V. \& Bauer C. (2000). "The Use of Web-Based Learning in Culturally Diverse Learning Environments”.Paper presented at the AUSWeb 2K, Sixth Australian World Wide Web Conference. Cairns, Queensland.

Chuah S. (2009). Teaching East-Asian Students: Some Observations. Retrieved from https://www. economicsnetwork.ac.uk/showcase/chuah_international

Clark J. C. \& Walsh J. (2002). "Elements of a Model of Effective Teachers”. Paper presented at the AARE Conference, Brisbane, 1-5 December. Retrieved from http://www.aare.edu.au.

Creswell J. (2013). Qualitative Inquiry and Research Design: Choosing Among Five Approaches. California 2013.

Çubukçu F. (2010). "Student Teachers' Perceptions of Teacher Competence and Their Attributions for Success and Failure in Learning”. The Journal of International Social Research 3/10 (2010) 213-217.

Demiröz H. \& Yeşilyurt S. (2015). "Effective Foreign Language Teaching: Perceptions of Prospective English Language Teachers”. Universal Journal of Educational Research 3/11 (2015) 862-870.

Dinçer A., Goksu A., Takkaç A. \& Yazıcı M. (2013). "Common Characteristics of an Effective English Language Teacher”. The International Journal of Educational Researchers 4/3 (2013) 1-8.

Dörnyei Z. (2007). Research Methods in Applied Linguistics: Quantitative, Qualitative and Mixed Methodologies. Oxford 2007.

Erbay Ş., Erdem E. \& Sağlamel H. (2014). “The Portrait of a Good Language Teacher: A Cross-Interview Analysis of Private Language Course Administrators' Opinions”. Turkish Online Journal of Qualitative Inquiry 5/4 (2014) 41-59.

Erişti B. (2012). "To Learn from Teachers at School, Ideal Teacher or E-Learning Applications from the 
Perspectives of Gifted Students”. Turkish Online Journal of Distance Education 13/4 (2012) 152-166. Faranda W. T. \& Clarke I. (2004). "Student Observations of Outstanding Teaching: Implications for Marketing Educators”. Journal of Marketing Education 26/3 (2004) 271-281.

Fry C. L. (1990). “Cross-Cultural Comparisons of Aging”. Ed. K. F. Ferraro, Gerantology: Perspectives and Issues (1990). New York.

Gao M. \& Liu Q. (2013). "Personality Traits of Effective Teachers Represented in the Narratives of American and Chinese Preservice Teachers: A Cross Cultural Comparison”. International Journal of Humanities and Social Science 3/2 (2013) 1-16.

Ghasemi B. \& Hashemi M. (2011). “The Study of the Characteristics of Successful English Language Teachers from the View Point of the English Language Studentsof Islamic Azad University”. Procedia-Social and Behavioral Sciences 28 (2011) 411-415.

Glaser B. \& Strauss A. (1967). The Discovery of Grounded Theory: Strategies for Qualitative Research.

Hativa N., Barak R. \& Simhi E. (2001). "Exemplary University Teachers: Knowledge and Beliefs Regarding Effective Teacher Dimensions and Strategies”. Journal of Higher Education 72/6 (2001) 699-729.

Hofstede G. J. (2005). “Humor Across Cultures: An Appetizer”. Retrieved from http://www.dialogin. com/fileadmin/Files/User_uploads/Humour.pdf

Hofstede G. J. (1991). Culture and Organization. London 1991.

Hunt B. C. (2009). Teacher Effectiveness: A Review of the International Literature and its Relevance for Improving Education in Latin America. (Working Paper No. 43). Washington 2009.

Kalebic S. C. (2005). “Towards the Development of Standards in Foreign Language Teacher Preparation”. Paper presented at $30^{\text {th }}$ ATEEA Annual Conference Amsterdam, Netherlands.

Kim K. J. \& Bonk C. J. (2002). “Cross Cultural Comparisons of Online Collaboration”. Journal of Computer-Mediated Communication 8/1 (2002).

Koç E. M. (2012). “Affective Characteristics and Teaching Skills of English Language Teachers: Perceptions of Elementary, Secondary, and High School Students”. Creative Education 4/2 (2012) 117-123.

Kourieos S. \& Evripidou D. (2013). “Students' Perceptions of Effective EFL Teachers in University Settings in Cyprus”. English Language Teaching 6/11 (2013) 1-16.

Larsen-Freeman D. (1986). Techniques and Principles in Language Teaching. New York 1986.

Lupascu A., Panisoara G. \& Panisoara I. O. (2014). “Characteristics of Effective Teacher”. Procedia Social and Behavioral Sciences 127 (2014) 534-538.

Malikow M. (2006). “Effective Teacher Study”. National Forum of Teacher Education Journal 16/3 (2006) 1-9.

Majid F. A. (2008). “Culture and Learner Beliefs: A Study of Three Malay Postgraduate Students”. Asian Journal University of Education 4/1 (2008) 127-142.

McDonough Jo \& Shaw C. (1993). Materials and Methods in ELT: A Teacher's Guide. Oxford 1993.

McLaughlin M. W. \& Marsh D. D. (1978). “Staff Development and School Change”. Teachers' College Record 80/1 (1978) 69-94.

Merriam S. B. \& Mohamad M. (2000). "How Cultural Values Shape Learning in Older Adulthood: The Case of Malaysia”. Adult Education Quarterly 51/1 (2000) 45-63.

Miles M. B. \& Huberman A. M. (1994). Qualitative Data Analysis: An Expanded Sourcebook. Thousand Oaks 1994.

Park G. \& Lee H. (2006). “Characteristics of Effective Teachers Perceived by High School Teachers and Students in Korea”. Asia Pacific Education Review 7/2 (2006) 236-248.

Pratt D. (1988). “Andragogy as a Relational Construct”. Adult Education Quarterly 38/3 (1988) 160-181.

Sakurai Y. (2012). "Learners’ Perceptions of Good Foreign Language Teachers: A Quantitative Analysis Between Native and Non-Native Teachers”. Electronic Journal of Foreign Language Teaching 9/1 (2012) 46-60.

Saraç-Süzer S. H. (2007). Examining Methodological Issues through Pedagogical and Practical-Knowledge 
of Experienced Teachers: A Case Study. Unpublished Doctoral Dissertation. Hacettepe University, Ankara 2007.

Shahmohammadi N. (2015). “Competent Teacher Character from Student Point of View”. Procedia-Social and Behavioral Sciences 205 (2015) 242-246.

Shishavan H. B. (2009). "Characteristics of an Effective English Language Teacher as Perceived by Iranian Teachers and Learners of English”. English Language Teaching 2/4 (2009) 130-143.

Simpson S. \& Mengi E. (2011). "What are the Characteristics of a Good Teacher?”. Paper presented at $15^{\text {th }}$ International INGED Conference: "Taking It to the Limits". Ankara, Turkey.

Tanaka K. \& Ellis R. (2003). “Study-Abroad, Language Proficiency, and Learner Beliefs about Language Learning”. JALT Journal 25 (2003) 63-85.

Telli S., den Brok P. \& Çakıroğlu J. (2008). “Teachers’ and Students’ Perceptions of the Ideal Teacher”. Ĕgitim ve Bilim 33/149 (2008) 118-125.

Terzino K. A. (2007). Culture and Forgiveness: A Prototype Perspective. Unpublished Doctoral Dissertation. Iowa State University 2007.

Thomas S. A. (1991). "Schooling for Success in a Non-Western Culture: A Case Study from Taiwan”. Journal of Qualitative Studies in Education 4/2 (1991) 109-120.

Thompson S. (2008). “Defining a Good Teacher Simply!”. Modern English Teacher 17/1 (2008) 5-14.

Walker R. J. (2008). “Twelve Characteristics of an Effective Teacher”. Educational Horizons 87/1 (2008) 61-68.

Wichadee S. (2010). “Defining the Effective English Language Teacher: Students' and Teachers' Perspectives”. Ed. A. M. Stoke, JALT 2009 Conference Proceedings (2010). Tokyo.

Wichadee S. \& Orawiwatnakul W. (2012). Characteristics of Effective Language Teachers as Perceived by Low and High Proficiency Students. European Journal of Social Sciences 31/3 (2012) 425-438.

Wong M. S. (2000). The Influence of Gender and Culture on the Pedagogy on Five WesternTeachers in China. Unpublished Doctoral Dissertation. University of South California, California 2000. 